\title{
Det Gamle Testamentes kanoniske status
}

\author{
Omkring Notger Slenczka, Vom Alten Testament und vom \\ Neuen. Beiträge zur Neuvermessung ihres Verhältnisses ${ }^{1}$ \\ Professor emeritus, dr.theol. \\ Mogens Müller
}

\begin{abstract}
Taking departure in the invitation in Slenczkas new book to discuss the role of the Jewish Holy Scriptures in a Christian canon, this article starts with contesting the validity of the arguments for introducing Old Testament readings in the service of the Danish Church. Reading the Old Testament in the light of Christian faith as if it in reality is about Christ was no longer possible after Enlightenment. With a historical and critical study, it became clear, that the Old Testament was Jewish and not Christian Scripture. In continuation of some deliberations in Luther, and especially the thoughts of F. Schleiermacher, A. von Harnack and R. Bultmann, Slenczka argues, that we today need to draw the consequence of this view. It was only in the reception of the Church that the Old Testament became a Christian text, and this cannot be ascribed a retroactive effect, a Jewish understanding and reception being much more appropriate. Its meaning in a Christian Bible, therefore, can only be to witness about man's place towards God without Christ. From this follows that in a Christian Bible the Old Testament cannot figure with the same degree of canonicity as the New, instead it should be reckoned at the same level as the Old Testament Apocrypha.
\end{abstract}

Key words: Old Testament as canonical Scripture - Notger Slenczka Martin Luther - Friedrich Schleiermacher - Adolf von Harnack - Rudolf Bultmann - Christianity-Judaism-relation.

\section{Indledning}

Notger Slenczka, professor i systematisk teologi ved Humboldt-Universitetet i Berlin, rejser med sin nye bog et spørgsmål, som også for den danske folkekirke og dens gudstjeneste er af allerstørste vigtighed. For holder de præmisser, som i 1992 lå til grund for den endelige indførelse af læsninger fra Det Gamle Testamente i kirkens tekstræk-

1. Leipzig: Evangelische Verlagsanstalt 2017. 506 sider. Pris 44 Euro. Nedenfor henvises der til Slenczkas bog med navn og sidetal. 
ker og dermed i gudstjenesten? ${ }^{2}$ Var - og er - det liturgisk-teologisk forsvarligt at have læsninger fra Det Gamle Testamente i en kristen gudstjeneste, hvad enten det er af skabelsesteologiske grunde eller af pædagogiske, fordi det kan rette op på den mangel på bibelkundskab, der opstod, da folkeskolens religionsundervisning ikke længere måtte være forkyndende og derfor ikke kunne gøre det ud for dåbsoplæring? For nu slet ikke at tale om den begrundelse, der gik ud på, at læsningerne fra Det Gamle Testamente kunne fungere som kontrasttekster, dvs. som negativ baggrund til læsningerne fra Det Nye Testamente. I en dengang ofte citeret vending i den indledende, såkaldte Grå Betænkning 750 (De bibelske lasninger i gudstjenesten) fra 1975 hed det, at det var hensigten, at "Det gamle Testamente skal lyde i kirken på sine egne betingelser" (199). Disse ord blev af Eduard Nielsen i Betænkning 1057 fra 1985 udfoldet til, at

udvalget er naturligvis foretaget ud fra den overbevisning, at netop de tekster, man har udvalgt, er de bedst egnede til på én gang at understrege, at kirken er en fortsættelse af Israel, af jødedommen og Det gamle Testamente, men også et brud med den verden. Fastholder man denne dobbelthed, kan man med god samvittighed tage gammeltestamentlige tekster med i gudstjenesten på "Det gamle Testamentes egne vilkår”, fordi man ved, at nogle af dem på en positiv måde forbereder evangeliet, andre gør det negativt, ved tekster, som $\mathrm{Ny}$ Testamente taler imod. ${ }^{3}$

Dermed synes Det Gamle Testamentes kanoniske ligestilling med Det Nye at være undsagt, og det kan i dag synes, at folk som min daværende biskop over Roskilde Stift, Hans Kvist (1911-1980), dengang havde ret $i$, at Det Gamle Testamente ganske enkelt ikke hører hjemme i folkekirkens gudstjeneste, og min lærer og senere kollega og

2. Forud var gået forskellige forsøgsordninger, begyndende med Den Grå Betænkning 750 i 1975. Jf. hertil Holger Villadsen, “'På gudstjenestens betingelser'. Om valget af gammeltestamentlige perikoper i Den Danske Alterbog (1992)", Bibelen i gudstjenesten, red. Gitte Buch-Hansen \& Frederik Poulsen, Publikationer fra Det Teologiske Fakultet 60 (København 2015) 109-127.

3. Eduard Nielsen, „Om de gammeltestamentlige læsninger ved gudstjenesten“, i Indledning. Forslag til Alterbog. Betænkning afgivet af Kirkeministeriets liturgiske kommission (København 1985) 32-39 (35). Det hører med til billedet, at Eduard Nielsen også kunne skrive artiklen: "Hvorfor kan man ikke prædike over Gammel Testamente?", Teologi og tradition, FS Leif Grane, red. Thorkild Grosbøll, Bent Hahn \& Steffen Kjeldgaard-Pedersen (Frederiksberg: Forlaget Aros 1988) 4961, hvor det afsluttende bl.a. hedder (60): "Hvis en kristen prædiken skal være et Kristus-vidnesbyrd, kan vi ikke med god samvittighed prædike over en tekst fra Det gamle Testamente. Det egentlige, det vi skal prædike om, findes ikke i teksten, før vi selv lægger det ind i teksten.” 
ven, Niels Hyldahl (1930-2015), fortrød på sine ældre dage ligeud, at han havde været med til det. ${ }^{4}$

Så det er en i høj grad betimelig bog, Slenczka nu har udsendt om forskellen mellem Det Gamle og Det Nye Testamente i kanonisk henseende. Hans synspunkter kommer ikke uforberedt, men går tilbage til en artikel fra 2013, som dog først i 2015, i forbindelse med en bedømmelsessag, fremkaldte et ramaskrig og ophidsede beskyldninger mod ham for at være markionit, hvis ikke ligefrem nazist. $\mathrm{Nu}$ har Slenczka så valgt i bogform ikke alene at udgive 2013-artiklen, "Die Kirche und das Alte Testament", ${ }^{5}$ men desuden forskellige indledninger og en længere række uddybende kapitler, derunder også en samling af prædikener over gammeltestamentlige tekster, som skal vise, at hans syn på denne del af Bibelen ikke udelukker den fra den kristne gudstjeneste. Bogens opbygning og karakter betyder, at den ikke er helt fri for gentagelser. Men sådanne skal efter sigende fremme forståelsen. ${ }^{6}$

\section{Det Gamle Testamente er kanonisk på linje med Det Gamle Testamentes Apokryfiske Bøger}

De kristne menigheder betragtede fra begyndelsen jødedommens hellige bøger som også deres hellige Skrift. Markions indsigelse imod dette i begyndelsen af 2 . århundrede kom alene til at cementere dette forhold. Og de skrifter, der siden kom til at udgøre Det Nye Testamente, forudsætter alle - selv om det ikke ligefrem kommer til udtryk i dem alle - at Loven, Profeterne og Skrifterne fuldt og helt også er deres Bibel. Og fra begyndelsen af mente de Kristus-troende tilmed, at de alene forstod disse skrifters budskab. Det fremgår allerede af Paulus' udredninger i 2 Kor 3,14-15 med talen om det slør, der ligger over jødernes hjerte, når Moses læses op, og som først fjernes i

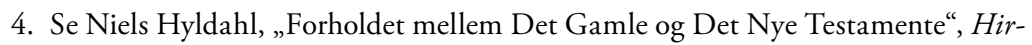
storie og konstruktion, FS Niels Peter Lemche, red. Mogens Müller \& Thomas L. Thompson, Forum for Bibelsk Eksegese 14 (København: Museum Tusculanums Forlag 2005) 207-213 (208).

5. Oprindelig i Elisabeth Gräb-Schmidt, red., Das Alte Testament in der Theologie. Marburger Jahrbuch Theologie 25 (Leipzig: Evangelische Verlagsanstalt 2013) 83119. Jeg har tidligere drøftet denne artikel i Mogens Müller, "Hører Det Gamle Testamente stadig hjemme i den kristne Bibel?” Buch-Hansen \& Poulsen (2015), 99-107.

6. Oversigten over oprindelige Ersterscheinungsorte (26-27) viser udgivelsens bibliografiske kompleksitet, idet der naturligt nok desuden har fundet en bearbejdelse sted af tidligere offentliggørelser. 
Kristus. I den treenighedslære, der blev formuleret i de følgende århundreder, udvikledes den forestilling, at den Gud, der kom til orde i jødedommens hellige skrifter, hele tiden også havde været Jesu Kristi far, idet Sønnen ikke først blev til ved sin fødsel, men ved denne lejlighed blev inkarneret. Det vil med andre ord sige, at åbenbaringen i Kristus skete med 'tilbagevirkende kraft'. Følgen er, at den jødedom, der 'nøjes' med den Gud, der kommer til orde i dens egne hellige skrifter, om ikke dyrker en anden gud, som Markion hævdede det, så dog i hvert fald kun har et begrænset gudsbillede. Det var den omstændighed, der fik Markion til at drage den konsekvens, at det i Det Gamle Testamente simpelt hen var en anden gud, der åbenbarede sig, skaberguden eller demiurgen, som han blev benævnt.

I den følgende tid stillede man sig tilfreds med en forståelse som den, der fandt et klassisk udtryk i Augustins formulering: "Det Nye Testamente ligger skjult i Det Gamle Testamente, Det Gamle Testamente er åbenbaret i Det Nye Testamente" (Quaestiones in Heptateuchum II,73). Dette kristologiske fortegn for forståelsen af Det Gamle Testamente blev det imidlertid vanskeligt, hvis ikke ligefrem umuligt at fastholde, da det med Oplysningstiden kom til en mere og mere konsekvent historisk og kritisk forståelse af Bibelens og dens tilblivelse. Skriftbeviset, som ved siden af Jesu undere havde udgjort det uimodsigelige grundlag for kristendommens sandhed, gik i opløsning. ${ }^{7}$ Treenighedsforestillingen kunne ikke længere sikre opfattelsen af Det Gamle Testamente som en i grunden kristen bog. 'Ubehaget' ved denne første del af Bibelen begyndte at gøre sig gældende. Og den forskel mellem de to skriftsamlinger, som man selvfølgelig hele tiden havde været opmærksom på, og som havde kaldt på forskellige forklaringsmodeller, blev hurtigt oplevet som graverende.

Med den viden, vi i dag har om Det Gamle - og Det Nye - Testamentes tilblivelse, og i lyset af forholdet til den jødedom, der naturligt nok ikke anerkender den klassiske interpretatio Christiana af deres hellige skrifter, må kristen teologi i dag arbejde ud fra den præmis, at Det Gamle Testamente historisk betragtet ikke er en kristen bog. Derfor kan dens skrifter ifølge Slenczka i en kristen Bibel heller ikke optræde med samme kanoniske status som de nytestamentlige, kristne skrifter. Det forholder sig desuden sådan, at tilføjer man til en eksisterende samling af hellige, autoritative skrifter en ny samling, der

7. Det var den apori, Hermann Samuel Reimarus endte i, da han i 1731 holdt en forelæsningsrække om "Rigtigheden (vindicatio) af de udsagn fra Det Gamle Testamente, der er påberåbt i Det Nye.” Se Mogens Müller, "Gør Oplysningstiden en forskel i kirkens bibelbrug?" Reformationen - Universitet - Kirkehistorie - Luther, FS Steffen Kjeldgaard-Pedersen, red. Tine Reeh \& Anna Vind (København: C.A. Reitzels Forlag 2006) 71-92 78f). 
skal være normgivende for forståelsen af den, får den første samling dermed en underordnet status og anden kanonisk rang. I modsat fald ville kristendommen også være jødedom, ligesom tilføjelsen af Mormons Bog til den kristne Bibel tilsvarende bevirker, at der med mormonerne ikke længere er tale om kristne. ${ }^{8}$ Reception kan derfor enten finde sted i skikkelse af udfoldelse, der lader udgangspunktet beholde sin egenbetydning, eller som overgreb, hvis den søger at påtvinge de grundlæggende tekster den forståelse og fortolkning, som først er udviklet i receptionen. Selv om man f.eks. går ind for muligheden for skilsmisse og ægteskab mellem to af samme køn, må det klart fremgå, at man ikke her har Bibelens bogstav, men nok dens ånd med sig.

\section{Luther og forholdet mellem Det Gamle og Det Nye Testamente ${ }^{9}$}

I sin "Fortale til Det Gamle Testamente" fra 1523 kan Luther udtrykke en lignende dialektik som Augustin gennem sin advarsel mod at agte Det Gamle Testamente ringe, for i det finder den kristne "den guddommelige visdom, som Gud her har fremsat saa enfoldigt og simpelt, for at holde alt Hovmod nede. Her finder du det Svøb og den Krybbe, som Kristus ligger i; dér viste ogsaa Englen Hyrderne hen. Simple og ringe er Svøbekludene, men dyrebar er den Skat, Kristus, som ligger deri." ${ }^{10}$ Ligesom Augustin-citatet understreger disse ord retningen fra Det Nye Testamente til Det Gamle Testamente. Luther var heller ikke i tvivl om, at der måtte en ny pagt til, for at man overhovedet kunne få øje på dette. Som det også hedder i "Fortalen", så er Det Gamle Testamente "en Lovbog", Det Nye Testamente "et Evangelium eller en Naadebog, og lærer, hvor man skal finde Lovens Opfyldelse."

Men ligesom der i Ny Testamente ved siden af Naade-Lære ogsaa gives megen anden Lære - Love og Bud til at regere kødet med, eftersom Aanden aldrig bliver fuldkommen i dette Liv, og derfor heller ikke idel

8. Grænsefænomener er her Jehovas Vidner og fundamentalister, der hævder, at Bibelen alene er Guds ord i deres bestemte forståelse af den.

9. Slenczka inddrager Luther i 2013-artiklen (54), men især i Teil I,5, "Luther und das Alte Testament" (217-232).

10. Citeret efter Gustav og Frede Brøndsteds oversættelse i Luthers Skrifter i Udvalg III (København: Gad 1964) 14. Den tyske tekst, "Vorrede auff das Alte Testament", er let tilgængelig i Hans Volz, red., D. Martin Luther, Die gantze Heilige Schrifft Deudsch (Wittenberg 1545) (Darmstadt: Wissenschaftliche Buchgesellschaft 1972) I 8-20. 
Naade kan regere - saaledes er der i det Gamle Testamente ved Siden af Lovene ogsaa Løfter og Naade-Tilsagn, paa hvilke de hellige Fædre og Profeter, under Loven, er blevne holdt oppe i Kristi Tro, saa vel som vi. Dog, som det Ny Testamentes egentlige Hoved-Lære er at forkynde Naade og Fred ved Syndsforladelse i Kristus, saaledes er det Gamle Testamentes egentlige Hovedsag at lære Lov, vise, hvad Synd er, og kræve, hvad Godt er (15).

Luther opdeler nu Lovens bud i tre afdelinger, nemlig i dem, der angår de timelige ting, ligesom de kejserlige love på Luthers tid, dem, der handler om gudstjenesten ydre former, samt endelig i dem, der står over begge disse og gælder "Loven om Troen og om Kærligheden, saaledes, at Troen og Kærligheden maa og skal være Maalestok for alle andre Love. Disse skal kun have Gyldighed, hvor de virker saaledes, at de ikke strider mod Troen og Kærligheden; men kommer de i Modstrid med Troen og Kærligheden, da skal de være helt ugyldige" (18-19). Det gælder desuden, at "ingen Lov-gerning gøres med Lyst og Kærlighed" (20). Derfor må der her tvang til, således "at Lov-gerning er Tvangs-gerning" (20), hvorfor Loven også først og fremmest åbenbarer synden. Derfor kalder Paulus også "Moses en "Syndens Embedsmand" og hans Embede et Dødens Embede, Gal. 2 og 3, 2 Kor. 3" (20). Loven skal således vise ud over sig selv, udvirke, at mennesket presses til "at søge noget andet, noget ud over Loven og egen Evne: Guds Naade, lovet og tilsagt i den Kristus, som skal komme" (23).

Derfor kalder ogsaa Paulus Mose Lov det Gamle Testamente eller Pagt; Kristus ligesaa, idet han indstifter den ny Pagt; og et Testamente er det, fordi Gud deri tilsagde og tilskødede Israels Folk Kanaans Land, om de vilde holde hans Lov; han overgav dem dette Testamente, og det blev beseglet ved Faars og Bukkes Død og Blod. Men fordi dette Testamente ikke hvilede paa Guds Naade, men paa Menneskers Gerninger, saa maatte det forældes og miste sin Gyldighed, og det lovede Land maatte tabes igen; thi Loven kan ikke opfyldes ved Menneskegerning. Derfor maatte der komme et andet Testamente, som ikke forældedes, og som ikke afhang af vore Gerninger, men af Guds Ord og Gerning, for at de kunde bestaa til evig Tid. Derfor er det ogsaa beseglet ved en evig Persons Død og Blod, og et evigt Land er dets Løfte og Gave (25). 
I det lille skrift, Eine Unterrichtung, wie sich die Christen nach Mose richten sollen fra 1526 - det går tilbage til en prædiken holdt i $1525^{11}$ - uddyber Luther, hvorfor Det Gamle Testamente, her sammenfattet som Moseloven, ikke gælder de kristne. For Moseloven har alene adresse til jøderne, som det f.eks. også fremgår af indledningen til De Ti Bud (Ex 20,1), og den angår derfor ikke hedningerne, som dog godt kan have nogle love fælles med jøderne, nemlig de bud, som hører hjemme i den naturlige lov, som hedningerne fra naturens hånd har indskrevet i deres hjerter (se Rom 2,14-15). Som Luther skriver: "Moses er død, hans regimente var forbi, da Kristus kom. Derfor er lovens tjeneste nu slut." Dog: "Vi vil godt anse Moses for en lærer, men vor lovgiver er han ikke, medmindre han stemmer overens med Ny Testamente og den naturlige lov" (27). Dennes bud, som Luthers læsere har adgang til i det "Sachsenspiegel", som deres land regeres efter, får altså ikke deres autoritet ved at stemme overens med Moseloven, "men fordi de er indplantet i min natur og stemmer overens med den" (30-31). Dette understreger Luther nu igen og igen i dette skrift (f.eks. 36-37).

Det, der ifølge Luther i Mosebøgerne tilhører hedningerne, er Guds forjættelser og løfter om Kristus: "Dette er det fornemste hos Moses, og det tilhører os hedninger" (31). Det er det springende punkt. For det er jo det, som jøden ikke kan se af sig selv, fordi det først åbenbares i Kristus. Med denne opfattelse, som går tilbage til Paulus, erklærer den kristne tolkning altså Det Gamle Testamente, for så vidt angår forjættelserne, for en lukket bog for jøderne. Her forstår de simpelt hen ikke deres egne hellige skrifter. Og Luther kan ud fra sine hermeneutiske forudsætninger ikke - som vi må i dag - sondre mellem tradition og reception. For ham må det, som vi bestemmer som tolkende overtagelse, nødvendigvis være fuldt, om end uudfoldet, til stede i teksten selv. Derimod er det et videreførende punkt i Luthers lille skrift, at f.eks. Moseloven ikke har adresse til andre end til jøderne, selv om det meget vel kan være Guds ord. "Man skal omgås Skriften med varsomhed. Ordet er blevet til på mange forskellige måder fra begyndelsen af. Man skal ikke kun se på, om det er Guds ord, om Gud har talt det, men meget mere se på, hvem der er talt til,

11. Luthers Eine Unterrichtung wie sich die Christen in Mose sollen schicken findes i WA 16, 363-393. Den originale tyske tekst samt en gengivelse på moderne tysk (i øvrigt ved Notger Slenczka) optræder i Dietrich Korsch, red., Martin Luther. Glaube und Leben. Deutsch-Deutsche Studienausgabe. Band 1 (Leipzig: Evangelische Verlagsanstalt 2012) 525-549. Her citeret efter den danske oversættelse i Martin Luther. Skrifter i udvalg. Troen og livet (København: Credo Forlag 1992) 23-39, der dog bygger på den forkortede og redigerede udgave, hvori Luther lod denne tekst optræde som indledning til sine prædikener over Første Mosebog, der i 1527 udkom på både tysk og latin. Se WA 24,1-16. 
om det har adresse til dig selv eller en anden" (33). Og her må vi i dag vedgå, at Det Gamle Testamente er skrevet af jøder og henvender sig til jøder. Der er her tale om aspekter i Luthers syn på Det Gamle Testamente, som nærmest fuldstændigt forsvandt i hvert fald i det meste af den danske Luther-reception. ${ }^{12}$

Når det gælder Luther, må man desuden holde sig for øje, at han ikke har en håndfast metode til at nå til forståelse af Skriften, men mener, at den alene åbner sig for den, der "under anvendelse af utrættelig iver (usus assidui studii)" er villig til at sætte sin lid til Åndens indflydelse. ${ }^{13}$ Således er skriftforståelse ikke blot en lærdomssag, men Luther gør radikalt "alvor af, at Bibelens ord er tiltale, og af, at Guds tiltales udlægning af mennesket og menneskets udlægning af Guds ord er to sider af samme sag." ${ }^{4} 4$ Samtidig gælder det for Luther, at ikke engang Det Nye Testamentes skrifter uden forskel kan bestemmes som Guds ord. For hvert skrift må måles på, "ob es Christum treibet”, dvs. på sin evne til at kalde troen på Kristus frem. ${ }^{15} \mathrm{Og}$ her mente Luther som bekendt udmærket at kunne skelne og endda skille enkelte ud og anbringe dem bagerst, til at begynde med endda uden for nummer. ${ }^{16}$

12. Det er en alvorlig indvending mod det ellers i mange henseender fortrinlige trebindsværk, Niels Henrik Gregersen og Carsten Bach-Nielsen, red., Reformationen i dansk kirke og kultur (Odense: Syddansk Universitetsforlag 2017), at det stort set lader skriftreceptionens historie og betydning i den lutherske kirke ude af syne. Ifølge Luther selv begyndte det hele med en ny indsigt i Skriften! For de reformatoriske kirker var det selve hovedsagen, at Bibelen for dem spillede en helt anderledes central rolle end for den katolske kirke.

13. Se for dette aspekt Jesper Høgenhaven, "Luther som bibelsk teolog", Skriften alene? Fem perspektiver på det lutherske bibelsyn, red., Kristoffer Garne, Palmeserien 1 (København: Tidsskriftet Fønix 2017) 9-37 (14-19).

14. Steffen Kjeldgaard-Pedersen \& Carl Axel Aurelius, Nåde og fred i Kristus. Martin Luther $i$ lyset af hans breve (København: Eksistensen 2017) 35, idet der til dette spørgsmål især kan henvises til Luthers brev til Georg Spalatin fra 18. januar 1518, i nævnte udgave 146-148. Jf. desuden Slenczka, 145-150.

15. Slenczka fremhæver i denne sammenhæng (111 n. 183; se desuden 127-128), at Inge Lønning, "Kanon im Kanon". Zum dogmatischen Grundlagenproblem des neutestamentlichen Kanon. Forschungen zur Geschichte und Lehre des Protestantismus 10. Rh Band 43 (Oslo: Universitetsforlaget/München: Chr. Kaiser Verlag 1972) modsat af, hvordan han undertiden er blevet forstået - ikke taler om kanon i kanon som et særligt udvalg af skrifter, men som den målestok, der på en og samme tid fremgår af samlingen af kanoniske skrifter, og som de hver især må måles på. Som Lønning formulerer Luthers opfattelse i fortalerne (110; kursiverne er Lønnings): "der Kanon (als regula fidei verstanden) ist und bleibt im Kanon (als vorhandene Schriftsammlung verstanden)."

16. Se hertil f.eks. Mogens Müller, "Luthers bibeltekst - en luthersk bibeltekst", Bibelen og Reformationen, red. Martin Friis, Mette Bundvad, Mogens Müller \& Gitte Buch-Hansen, Forum for Bibelsk Eksegese 20 (kun udgivet som e-bog). (Kø- 
Den dialektik, som kan hindre, at jødedommens hellige bøger læses på deres egne præmisser, forudsatte altså en eller anden udgave af et inspirationsdogme, der lod teksterne udspringe af Helligåndens tale. Som Slenczka viser det (155-156), fastholder Ortodoksiens store teologer som David Hollaz (1648-1713) og Johann Andreas Quenstedt (1617-1688) dette i deres lære om testimonium Spiritus Sancti internum. For den skal ikke forstås om det, at Ånden vækker overbevisningen om Skriftens guddommelige oprindelse, men om at Ånden gennem Skriften vækker den retfærdiggørende tro på Kristus. Ellers kunne det lutherske sola scriptura-princip i Ortodoksiens tidsalder undertiden gøre sit til at fjerne fornemmelsen for, at Moseloven ikke havde adresse til kristne, og at Det Gamle Testamente skulle læses med et kristologisk fortegn. Det skete for eksempel, da man i Danmark erstattede kanonisk ret med Moseloven helt ud i dens mest barbariske bestemmelser. ${ }^{17}$ Først med Oplysningstiden blev der løst op for denne krasse biblicisme, og i kraft af en stadigt voksende historisk og kritisk læsning blev det nærliggende at forstå Det Gamle Testamente som først og fremmest udtryk for israelitisk-jødisk religion.

\section{Slenczkas tre nyere hovedvidner}

I 2013-artiklen førte Slenczka sine tre hovedvidner i skranken for den opfattelse, at Det Gamle Testamente ud fra en historisk-kritisk forståelse ikke læses som udtryk for Kristus-tro. Det drejer sig om Friedrich Schleiermacher, Adolf von Harnack og Rudolf Bultmann. For Schleiermacher (1768-1834) står det således klart, at Det Gamle Testamente er udtryk for en i forhold til Kristus-troen fremmed from bevidsthed. Selv om den Kristus-troendes fromme bevidsthed måske nok kan genfinde sig selv i f.eks. dele af Salmerne, støder den dog også der på tekster, der vækker anstød og ikke tillader ham helt at tage salmen som udtryk for sin egen gudsbevidsthed. Og det kan ikke undre, da disse tekster ikke er udsprunget af en kristen trosbevidsthed. Det betyder selvfølgelig ikke, at Schleiermacher ikke anerkender, at Det Nye Testamente befinder sig i en religionshistorisk sammenhæng med Det Gamle Testamente, dvs. 'senjødedommen', men det er for

benhavn: Det Teologiske Fakultet i samarbejde med Eksistensen Akademisk 2017) 35-55 (41f).

17. Se hertil Tine Reeh, "Et fromt forsvar imod bål og brand. Professor Jeremias Friedrich Reuss' indlæg i sagen om sodomisten Niels Nielsen”, Teologien i historien - Historien i teologien. FS. Lauge O. Nielsen, red. Carsten Selch Jensen \& Christian Gottlieb, (København: Eksistensen 2016) 215-235. 
ham ikke tilstrækkeligt til, at de to bibeldele i kanonisk henseende kan have samme rang. Som det hedder som $\$ 12$ i hans Glaubenslehre:

Das Christenthum steht zwar in einem besonderen geschichtlichen Zusammenhange mit dem Judenthum; was aber sein geschichtliches Dasein und seine Abzweckung betrifft, so verhält es sich zu Judenthum und Heidenthum gleich. ${ }^{18}$

For Schleiermacher er det altså i denne sag ikke afgørende, at jødedommen repræsenterede monoteismen, for i kraft af kristendommen blev monoteismen også hedningeverdenen til del.

Alt dette hviler naturligvis på Schleiermachers forståelse af religion som menneskets selvforståelse og dennes udtryksformer. Slenczka citerer i den forbindelse en passage fra femte tale i Reden über die Religion: ${ }^{19}$

Et individuum af religionen, som vi søger det, kan kun komme i stand, ved at en eller anden enkelt anskuelse af universet vilkårligt ... bliver gjort til hele religionens centrum, og at alt i religionen relateres til den. Derved kommer på en gang en bestemt ånd og en fælles karakter ind i helheden. Alt, hvad der tidligere var mangetydigt og ubestemt, bliver fikseret, af de uendelig mange forskellige opfattelser og forbindelser af enkelte elementer, som alle var mulige, og som alle burde gengives, realiseres gennem enhver sådan formation én. Alle enkeltelementer fremtræder nu fra den samme side, nemlig den, som er vendt mod det centrum, og alle følelser får netop derved en fælles tone og bliver mere levende, idet de griber ind i hinanden.

Kort sagt: I kraft af universaliseringen af gudsforholdet i Jesu forkyndelse og gennem den bestemte religiøse bevidsthed, der opstod derigennem, løfter kristendommen sig ud af jødedommen og adskiller sig fra den. Derved kan de samme forestillinger i kraft af deres nye indplacering få en anden vægt og en forskellig betydning. ${ }^{20}$

Adolf von Harnack (1851-1930) er i denne sammenhæng især kendt for sine ord i Marcion-bogen fra 1921 om, at det ville have været

18. Der christliche Glaube 1 (Berlin: Reimer $\left.{ }^{2} 1830\right) 84$.

19. Slenczka, 64. Her anført efter Friedrich Schleiermacher, Om Religionen. Taler til de dannede blandt dens foragtere (1799). Oversat af Birgit Berggrensson i samarbejde med Theodor Jørgensen (Frederiksberg: Aros 2010) 183. Schleiermacher udvikler siden sit syn i Der christliche Glaube 2 (Berlin: Reimer $\left.{ }^{2} 1831\right) 380(\$ 132,2)$. 20. Slenczka uddyber sin Schleiermacher-forståelse i kapitlet "Lob der Religion als eines bildenden Sprachgeistes.' Theologische Implikationen der Hermeneutik Schleiermachers" (277-290). 
en fejl, hvis kirken i det 2. århundrede havde forkastet Det Gamle Testamente, mens det, at det ikke skete i det 16. århundrede, var en skæbne, som Reformationen endnu ikke magtede at unddrage sig, "men efter det 19. århundrede i protestantismen stadig at konservere det som kanonisk aktstykke, er følgen af en religiøs og kirkelig lammelse" ${ }^{21}$ Harnack havde af Den Religionshistoriske Skole lært, at religion er et fænomen, der udvikler sig, og hvor et senere trin i forhold til de forudgående udtrykker en større fuldkommenhed. Den nye gudstro, som bryder igennem med Jesus, kan derfor ikke længere være begrænset af sin forhistorie. Denne erkendelse kom det imidlertid ikke til på én gang. Først i løbet af historien kunne kristendommen nå til klarhed over sin egenart i forhold til Israels religionshistorie og fra denne fulde erkendelse, som det ikke kom til med Reformationen, men først i dennes kølvand, få et afklaret forhold til Det Gamle Testamente. For taget for sig er denne skriftsamling vidnesbyrd om en stammereligion med en fordring på partikularitet og kan derfor ikke være kanonisk på linje med Det Nye Testamente.

Det tredje og sidste vidne, som Slenczka påberåber sig for at tildele Det Gamle Testamente en anden grad af autoritet inden for kanon og teologi end Det Nye Testamente, er Rudolf Bultmann (1884-1976). ${ }^{22}$ Her sker det imidlertid på ganske andre præmisser. Bultmann kan ikke tilkende en objektiverende religionshistorisk forsknings historiserende bestemmelse af forholdet mellem de to dele af Bibelen teologisk relevans. For på den måde læses både Det Gamle og Det Nye Testamente som skrifter, der handler om begivenheder i fortiden. Over for en sådan objektiverende læsning sætter Bultmann sin eksistentiale interpretation, der opfatter en tekst som udtryk for en menneskelig selvforståelse, som til enhver tid byder sig til som en forståelig og realisérbar selvforståelse. Lov og evangelium (nåde) lader sig således ikke fordele på henholdsvis Det Gamle og Det Nye Testamente. Også Det Gamle Testamente indeholder nemlig evangelium, nemlig i skikkelse af Guds udvælgelse og lovgivning. Men dette har alene adresse til jødedommen, mens den kristne menighed, kirken, er konstitueret af

21. Adolf von Harnack, Marcion. Das Evangelium vom fremden Gott. Her anført efter 2.-udgaven (Leipzig: J.C. Heinrichs Verlag 1924 = Nachdruck Darmstadt: Wissenschaftliche Buchgesellschaft 1960) 217. Hos Harnack er ordene ligefrem spatierede.

22. Hovedreferencen er her Bultmann-artiklen "Die Bedeutung des Alten Testaments für den christlichen Glauben“, første gang offentliggjort i samme, Glauben und Verstehen. Gesammelte Aufsätze I (Tübingen: Mohr (Siebeck) 1933, $\left.{ }^{2} 1954\right)$ 313336. Se også Katrine Winkel Holm, Det gamle Testamente som teologisk problem. Tekst \& Tolkning 12 (København: Museum Tusculanums Forlag 2000). 
det forkyndte ord om Guds tilgivelse i Kristus. En vigtig passage hos Bultmann om dette spørgsmål lyder i min oversættelse: ${ }^{23}$

\begin{abstract}
Men det betyder også: For den kristne tro er Det Gamle Testamente ikke langere åbenbaring, således som det var og er det for jøderne. For den, der står i kirken, for den er Israels historie fortid og bragt ud af verden. Den kristne forkyndelse kan og skal ikke erindre tilhørerne om, at Gud førte deres fædre ud af Egyptens land, at han engang førte folket i fangenskab og igen bragte det tilbage til det forjættede land, at han på ny opbyggede Jerusalem og templet osv. Israels historie er ikke vores historie, og for så vidt Gud i denne historie har handlet nådigt, så gælder denne nåde ikke os. Netop derfor er det også muligt ud fra et kristent synspunkt at betegne Det Gamle Testamente som lov; ud fra sit eget synspunkt er det dog lige så godt lov som evangelium.
\end{abstract}

Slenczka vil nu med udgangspunkt i disse tre 'fædre' hævde, at det i dag ikke længere kan være teologisk legitimt at se bort fra Det Gamle Testamentes eget ståsted og f.eks. i forlængelse af en helbibelsk teologi à la Brevard Childs' operere med receptionshistorien som en tilladelse til at læse hele Bibelen i lyset af Kristus-troen. ${ }^{24}$ Det er et kristent overgreb på denne måde at læse Det Gamle Testamente så at sige helt på linje med Det Nye Testamente, dvs. som en helt igennem ligeværdig del af kanon. Det er en tilsidesættelse af den kendsgerning, at Det Gamle Testamentes tekster grundlæggende er skrevet ud fra en anden selv- og gudsforståelse end Det Nye Testamentes og dermed en fornægtelse af, at der ifølge kristen tro er sket noget helt og aldeles nyt med Kristus, en ny skabelse (Gal 6,15; 2 Kor 5,17). Således kan Slenczka også runde sin 2013-artikel af med at inddrage Paulus, først og fremmest Rom 9-11.

\title{
Det Gamle Testamente kan i dag ikke fastholdes som en kristen bog
}

Det Gamle Testamente er som en samling af jødedommens hellige skrifter altså i sig selv en jødisk bog. Læser man ud fra en kristologisk

23. I "Hører Det Gamle Testamente stadig hjemme i den kristne Bibel?” 106, hvor også den tyske tekst ("Die Bedeutung", 333) findes.

24. Fra den tyske debat nævner Slenczka (454) som et eksempel på en ekstrem forståelse med modsat fortegn Friedrich-Wilhelm Marquardt (1928-2002), Was dürfen wir hoffen, wenn wir hoffen dürtten? Eine Eschatologie (Gütersloh 1993), der hævdede, at kristne som ikke-jøder kun med jødisk accept kan være omfattet af frelsen. 
forudsætning evangeliet ind i dets skrifter, må man være sig bevidst, at man har gjort det til udtryk for en anden tro end den, som det selv er båret af. Også selv om kristen teologi fra først af forstod sig selv i forlængelse af åbninger over for en fremtid under nye vilkår som den, der finder sit udtryk i forestillingen om en ny pagtsslutning på helt andre betingelser end Sinajpagtens (se især Jer 31,31-34; Ez 36,2528). For selv om en række steder i Det Gamle Testamente har et udblik til hedningeverdenens kommende frelse, retter forkyndelsen i denne skriftsamling sig udelukkende til det israelitisk-jødiske folk.

Et entydigt udtryk for, at der således er tale om en 'stammereligion', optræder i Jubilæerbogens forkyndelse af Israels udvælgelse: Over alle de andre folkeslag lod Herren "herske ånder, som skulde lede dem bort fra ham. Men over Israel satte han ingen som helst engel eller ånd; thi han alene er deres hersker, og han vil vogte dem og kræve dem af sine engles hånd og af sine ånders hånd og af alle sine magters hånd for at vogte og velsigne dem, og for at de kan være hans og han være deres fra nu og til evig tid" (Jub 15,32-33; jf. Deut 32,8-9, der unægtelig her har făet en 'stramning').

Det 'ubehag', som Schleiermacher forklarer ved, at Det Gamle Testamente er skrevet ud fra en i forhold til Kristus-troen fremmed fromhed, afspejler sig også i, at de gudstjenestelige tekstrækker ikke blot består af et udvalg, men desuden undertiden også må gribe til at beskære tekster, for at de ikke alt for åbenlyst skal afsløre deres fremmedhed. Et talende eksempel er Salme 137, som man vel næppe ville læse til ende ved en kristen gudstjeneste. Når denne 'fremmedhed' alene kan undgås ved udeladelse af dele af teksten, er det et tegn på, at man læser noget ind i den, som den ikke selv kan kendes ved. Vil man fastholde denne indlæste betydning, kommer det ud på ét med kirkens gamle påstand om, at jøder, der ikke kan dele denne forståelse, ganske enkelt ikke forstår deres egne hellige skrifter rigtigt. Der bliver i givet fald tale om en forståelse, der ikke vil vedgå, at den er udtryk for en reception, der ikke kan gøre krav på at være den eneste rigtige. For en reception sker naturligvis med tilbagevirkende kraft, men den ændrer alene forståelsen af udgangspunktet, ikke selve udgangspunktet. Dertil kommer den omstændighed, at den ikke-skolede kirkegænger selvfølgelig må høre det oplæste bogstaveligt i den forstand, at hun eller han ikke lige indsætter et 'kristologisk forbehold', men umiddelbart må slutte, at teksten i sig selv giver udtryk for kristendom. Dette er i øvrigt et grundlæggende problem med hele 
den gammeltestamentlige del af bibelhistorien brugt som led i indførelsen i den kristelige børnelærdom. ${ }^{25}$

Når Slenczka skal begrunde Det Gamle Testamentes fortsatte plads i den kristne Bibel, selv om man altså ikke længere kan tillade sig at læse det med det kristologiske fortegn, der i sin tid betingede dets status som Bibel for de første kristne, er det med, at denne skriftsamling bedre end noget andet giver udtryk for det gudsforhold, mennesker kan have uden for Kristus-troen. ${ }^{26}$ Her tænker Slenczka videre i de baner, som Luther gav udtryk for i sin tale om, at Moseloven alene har adresse til jøder, for så vidt den ikke er i overensstemmelse med den naturlige lov. Derfor må det i dag gælde, at Det Gamle Testamente hverken vidner om Jesus Kristus eller den treenige Gud, men netop er udtryk for den religion, som de tidligste Kristus-troende voksede op med og havde, indtil de mødte forkyndelsen af Jesus som Kristus.

For der kom noget grundlæggende nyt til med Det Nye Testamente og kristendommen (se 326-330: "Was ist das 'Neue' am 'Neuen Testament und am Christentum?”). Foruden til Paulus' tale om "ny skabelse" henviser Slenczka i denne forbindelse til treenighedslæren og dens udfoldelse af Guds selv-definition i Jesus Kristus. Han inddrager her dels officerens bekendelse ved Jesu kors, der omfatter gudsforladthedens råb, dels - og måske nok så overbevisende - Paulus' citat i Fil 2,5-11, den såkaldte Filipperbrevshymne, hvor den korsfæstede ved sin ophøjelse af Gud får skænket navnet over alle navne. For "navnet over alle navne" må være det gammeltestamentlige gudsnavn, кúpıos, og ved at Jesus får det, bliver den Gud, der forkyndes,

25. Således mente heller ikke Grundtvig, at Det Gamle Testamente udtrykker den kristne tro. Som han kan udtrykke det i Haandbog $i$ Verdens-Historien. Efter de bedste Kilder. Et Forsøg (1833); optrykt i og her anført efter Holger Begtrup, N. F. S. Grundtvigs Udvalgte Skrifter Bind 6 (København: Gyldendalske Boghandel Nordisk Forlag 1907) 23 (spatieringer er afløst af kursiveringer): "Om vi vil være Christne eller ikke, derom spørges ei i Skolen men kun i Kirken, og det er desuden vor egen Sag, hver især, men naar Man havde lært Christendommens Historie rigtig i Skolen, da vilde Man ogsaa vide, det var først efter Reformationen de Skrift-Kloge fik det fortvivlede Indfald at giøre ikke blot Christi og Apostlernes Levnets-Beskrivelser, men hele den Jødiske Historie til Kirkelige Troes-Artikler og, for en Feils Skyld, til videnskabelige Axiomer." Jf. desuden 50: "Theologerne" har uheldigvis "siden Reformationen havt den Grille, at Jødernes hellige Skrift var Klippen hvorpaa den Christne Kirke var bygt, og at paa den skulde de slaae med deres Pen som en Moses-Stav, saa der sprang en Troes-Artikel ud af hvert Bogstav." (Jeg takker Anders Holm for hjælp til at finde disse henvisninger). Det må også få den konsekvens, at det, hvor der er tale om dåbsoplæring, må være Det Nye Testamente, der bliver lagt til grund. Kristentroen begynder ikke ved skabelsen, men ved troen på Jesus som opstanden fra de døde.

26. Det er dette forhold, Slenczka vil vise i de 10 meditationer og prædikener over gammeltestamentlige tekster - i ét tilfælde gælder det endda en apokryf, nemlig Visdommens Bog - der er inkluderet i hans bog (337-417). 
en anden, end han var før. Samme skifte ser Slenczka i begyndelsen af Johannesevangeliets prolog i identifikation af "logos" med Jesus: I ham bliver det åbenbaret, hvad der er meningen med al virkelighed. "Und dieser Logos ist nicht nur 'bei' Gott, sondern Gott 'ist' der Logos (Johannes 1,1-3), eins mit ihm, und doch als der Vater vom Sohn unterschieden" (327). I en afsluttende, selvstændig behandling om treenighedslæren (485-504: "Zur Verständigung über die Trinitätslehre im christlich-jüdischen Dialog”) uddyber Slenczka sin opfattelse af, hvordan gudsopfattelsen forandrer sig i Kristus-forkyndelsen. Gud åbenbarer sit væsen i sine handlinger over for mennesker, og derfor ændrer opfattelsen af den Gud, hvis væsen kommer til udfoldelse i hans forhold til Israel, sig til en anden opfattelse i troen på hans henvendelse til alle folk. Disse nye betingelser kommer tilmed ifølge Det Nye Testamente også til at gælde Israel. Guds handlen i historien er således identitetsskabende. Og Slenczka bruger det meget voldsomme billede, at en forbilledlig far, der begår et koldblodigt mord, derigennem får en ny identitet: Hans hidtidige liv træder ind under det fortegn, som hans identitet som morder sætter. Han er ganske enkelt ikke længere (kun) den gode far, som han engang var. Læser man tilsvarende den senere, 'nytestamentlige' identitet ind i gammeltestamentlige tekster, fremmedgør man dem for deres egen verden. Ifølge den nytestamentlige forkyndelse er Gud ikke én over for Israel, en anden over for folkeslagene.

\section{Tillæg: Hvad skal kristen teologi stille op med Det Gamle Testamentes forjættelser til Israel?}

Som tysker er Slenczka naturligt nok meget omhyggelig med at understrege, at han med sin kritik af forskellige former for "bibelsk" Israel-teologi ikke kritiserer den moderne stat Israels eksistensret. Hvad den angår, må Bibelen imidlertid tages af bordet. Enhver form for kristen zionisme, der taler om en bibelsk ret for jøderne til landet, må på forhånd afvises. Slenzcka fremdrager her som et eksempel på en biblicistisk forståelse af Israels plads i eskatologien Johann Tobias Beck (1804-1878) og hans posthumt udgivne Vorlesungen über christlichen Glaubenslehre 1-2 (1886-88). Her trækkes hele registret ud i tonesætningen af det israelitisk-jødiske folks kommende herlighed, hvor supranaturale kræfter spiller ind i dannelsen af en teokratisk stat. Vi kan herhjemme henvise til Peder Madsen (1843-1911), der i sin - af Lorenz Bergmann posthumt udgivne - Den kristelige Troslare 
(1912-13) dog neddæmper tonelejet i sin udlægning af talen i Rom 11,25-26 om, at derefter skal "hele Israel" frelses:

Efter at Missionen har omspændt alle Hedningefolkene og vundet de villige Mennesker iblandt dem, kommer Tiden endelig for Jødefolket; medens i de mellemliggende Aarhundreder kun enkelte Israelitter har omvendt sig, skal til den Tid Folket som Folk tage imod Evangeliet. Det vil ikke sige alle Israelitter uden Undtagelse; thi saaledes kan man aldrig tale om et Folk i aandelige Ting; der er altid visne Grene paa Træet, uimodtagelige Medlemmer, der ikke er villige til at deltage i Folkets Virkeliggørelse af sin aandelige Bestemmelse. Men Folket som Helhed skal omvende sig, altsaa saaledes at dets Folkebevidsthed, Folkeskik og Folkeliv skal være gennemtrængt af Kristendommen. Det er det eneste Folk, der har en saadan Forjættelse i Guds Ord, og derfor vel ogsaa rimeligvis det eneste, $\mathrm{i}$ hvem en saadan Tilstand bliver virkeliggjort (726).

Længere ville Peder Madsen ikke gå. Han afviste således fortolkere som J.A. Bengel (1687-1752) og J.Ch.K. Hofmann (1810-1877), der tillægger det jødiske folk

en langt mere omfattende Særstilling inden for den sidste Tids Kristenmenighed: det skal vende tilbage til Kanaans Land, hvor det med det genopbyggede Tempel som sit Midtpunkt skal leve i enestaaende indvortes og udvortes Herlighed med det aandelige Herredømme over alle de kristne Folkeslag (726).

Alle sådanne spekulationer om en særstilling for det jødiske folk i en kristen-teologisk sammenhæng må dog falde til jorden i dag. ${ }^{27}$ Paulus' forsøg på at komme til rette med dette spørgsmål i Rom 9-11 optræder rigtig nok i et kanonisk skrift, men kan ikke derfor blive en forpligtende trossætning. ${ }^{28} \mathrm{Og}$ ligegyldigt hvilken indramning man

27. At dette synspunkt dog ikke deles af alle 'kristne' teologer, kan ses hos den allerede (note 22) nævnte tyske Friedrich-Wilhelm Marquardt, der gjorde sig til talsmand for den forståelse af den gammeltestamentlige forjættelse om landet, at den berettiger den etniske udrensning, som er sket og fortsat sker i Palæstina i sporet på staten Israels oprettelse i 1948. I et andet tilfælde, Berthold Klappert, „Erwählung und Rechtfertigung. Martin Luther und die Juden" [1983], samme, Miterben der Verheißung (Neukirchen 2000) 105-147, finder Slenczka (472-473), at ,imødekommenheden' over for den jødiske forståelse af Det Gamle Testamente er så stor, at det rejser spørgsmålet: "Warum sollte man dieses Problem nicht lösen durch Anerkennung des Judentums und durch Konversion zum Judentum?"

28. Jf. Niels Hyldahl, "Jødedom, kristendom og fred på jorden”, i samme, Noget om Paulus - artikler 1973-2011. Publikationer fra Det Teologiske Fakultet 29 (Køben- 
giver sådanne frelseshistoriske spekulationer, bliver der tale om et bedrevidende overgreb på det jødiske trossamfund, hvor almindelig mission ved forkyndelse af evangeliet erstattes af en forestilling, der i praksis - og som et udslag af noget, som jeg kun kan forstå som antisemitisme - udelukker jøder fra at høre evangeliet i den nærværende tid.

\section{Slutning}

Slenczkas Vom Alten Testament und vom Neuen er en meget righoldig bog, og det har ikke været muligt her at komme ind på alle de temaer og de spørgsmål, som den rejser. Den er en guldgrube af kirkehistorisk viden, og forfatteren har et imponerende indblik i den nyere eksegetiske debat om forstålsen af Det Gamle Testamente som en del af den kristne kanon. Emner som f.eks. 'the parting of the ways' og kapitlet "'Rechtfertigungslehre' - Reformulierung im Licht des christlich-jüdischen Dialog" (464-484) kunne udmærket have fortjent en udførligere behandling. Men jeg har altså tilrettelagt denne anmeldelsesartikel først og fremmest som en frugtbargørelse af Slenczkas bidrag som anledning til en i dansk sammenhæng nødvendig genoptagelse af drøftelsen om Det Gamle Testamentes plads i kristen teologi og gudstjeneste.

havn 2011) 57-71 (71), hvor Hyldahl skriver, at Paulus med sin henvendelse til de romerske kristne om hjælp til mission i Spanien for dermed at nå til verdens ende og dermed opfylde betingelserne for Jesu genkomst ikke har anden begrundelse for denne storslåede strategi "end netop de dunkle ord om hedningernes fylde og Israels frelse i Rom 11,25-27, og de er og bliver udtryk for ønsketænkning fra Paulus' side, som han møjsommeligt har arbejdet sig frem til i løbet af Rom 9-11, men ikke vidste besked med, før han udarbejdede disse kapitler" (ordene er kursiverede hos Hyldahl). Betegnende nok vender apostlen da heller ikke senere i Romerbrevet (f.eks. i 15,7-13) tilbage til disse overvejelser. 